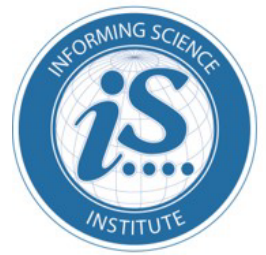

Interdisciplinary Journal of E-Skills and Lifelong Learning

An Official Publication

of the Informing Science Institute

InformingScience.org

IJELL.org

Volume 14, 2018

\title{
AN EXAMINATION OF GEN Z LEARNERS ATTENDING A MINORITY UNIVERSITY
}

Nicole Buzzetto-Hollywood*

Ayodele Alade

*Corresponding Author
University of Maryland Eastern

Shore, Princess Anne, MD, USA

University of Maryland Eastern

Shore, Princess Anne, MD,USA
Nabuzzetto-more@umes.edu

Ajalade@umes.edu

\section{ABSTRACT}

Aim/Purpose

This paper presents the preliminary findings of a pilot survey that sought to examine the technology uses, backgrounds, needs, interests, career goals, and professional expectations of Generation $Z$ students enrolled at a minority serving institution in the United States Mid-Atlantic region.

Background

Students entering college today are part of Generation Z born in the late 90's through 2016. Known for their short attention spans and heightened ability to multi-task, they already outnumber millennials and are the first true digital natives born during the age of smart phone.

Methodology

In the fall of 2017, an online student perception survey was piloted with students enrolled at a mid-Atlantic minority serving institution. The survey included a combination of dichotomous, Likert-scaled, and ranking questions. The survey was administered electronically using the Survey Monkey system to students following completion of core computer concepts courses and explored their technology backgrounds, skills, perceived computing self-efficacy, and the role they predict technology will play in their future career. The data was subsequently exported to Microsoft Excel and SPSS where descriptive statistical analyses were conducted.

Contribution As Generation Z descends on college campuses, with their technology dominated backgrounds and different communications, learning, and social preferences, it is important to better understand this generation whose needs and expectations will help shape the future of higher education. Additionally, this study also provides research on a population (first-generation minority college students) that is expanding in numbers in higher education and that the literature, reports is impacted negatively by the digital divide and educational inequalities. This paper is timely and relevant and helps to extend our understanding of Generation Z.

Accepted by Editor Fay Sudweeks | Received: December 10, 2017| Revised: February 22, 2018 | Accepted: February 23, 2018.

Cite as: Buzzetto-Hollywood, N., \& Alade, A. (2018). An examination of Gen Z learners attending a minority university. Interdisciplinary Journal of e-Skills and Lifelong Learning, 14, 41-53. https://doi.org/10.28945/3969

(CC BY-NC 4.0) This article is licensed to you under a Creative Commons Attribution-NonCommercial 4.0 International License. When you copy and redistribute this paper in full or in part, you need to provide proper attribution to it to ensure that others can later locate this work (and to ensure that others do not accuse you of plagiarism). You may (and we encourage you to) adapt, remix, transform, and build upon the material for any non-commercial purposes. This license does not permit you to use this material for commercial purposes. 
Findings

Recommendations for Practitioners

Recommendation for Researchers

Impact on Society

Future Research

Keywords
The findings show that Generation $Z$ learners enrolled in a minority-serving institution enjoy computer classes, feel that using computers comes easy to them; and perceive themselves as experts in the use of social media, mobile operating systems, using a smart phone, searching the Web, and email. Participants also reported that they want to be more technologically literate, want to be more skilled in computer software applications, and are interested in learning about cyber security. In terms of the future, most respondents also believe that their career will require them to analyze information to inform decision making. Additionally, most stated that information security will be important to their future career. Finally, the results affirmed that college computing courses remain important and that college students recognize that technology will play a crucial role in their career with employers wanting to see job applicants with strong technology skills.

Generation Z learners enrolled in higher education need, and want, a wide range of technology courses available to them in order to help them meet the rapidly evolving demands of tomorrow's workplace. Students in this study overwhelmingly see the value in enhancing their technology skills especially in such areas as computer software applications, information management, and cyber security.

Institutions of higher education should invest in thorough and ongoing examinations of the information and technology literacy skills, needs, and perceptions of students.

Understanding the interests and needs of Generation $\mathrm{Z}$ learners is imperative to the future of higher education.

This survey is a work in progress that is part of a pilot study that is being used to help guide a much more sizable examination of Generation $\mathrm{Z}$ learners.

technology skills, career readiness, technological literacy, Generation Z, computer concepts course, computer education, computer skills assessment, UMES, minority learners, career and technology readiness, technology assessment, digital literacy, computer self-efficacy

\section{INTRODUCTION}

For years, we have discussed millennials who were born between 1980 and 1996ish, but things are changing. Students entering college today are part of Generation Z, born in the late 90's through 2016, making the oldest among them 20 or so years old. They are the first generation that used a tablet before they could ride a bike, the first to have childhood friends that they played with electronically, and the first to have their births and baby photos and elementary school recitals shared on social media. Their minds, relationships, learning preferences, emotional health, sense of self, have all been inexplicably shaped by constant exposure to screens (Gibson, 2016).

In the fall of 2017, a survey was administered to 160 students who had completed an entry-level computer concepts and applications course at the University of Maryland Eastern Shore (UMES), a Historically Black, 1890 land-grant institution and member of the University system of the State of Maryland. The institution primarily serves first generation, low income, and minority learners with an enrollment of approximately 3400 as of the Fall of 2016. The survey sought to explore participants' technology backgrounds, device usage, perceived computing self-efficacy, and the role they predict technology will play in their future career. This survey is a work in progress that is part of a pilot study that is being used to help guide a much more sizable examination of Generation $\mathrm{Z}$ learners. 


\section{LITERATURE REVIEW}

Over 74 million strong, Gen Z makes up almost one-quarter of the U.S. population. They already outnumber any current living generation and are the first true generation of digital natives (Williams, 2015). According to Shatto and Erwin (2016), Generation $\mathrm{Z}$ is incredibly savvy when it comes to mobile technologies and self-directed learning; however, they lack critical thinking skills as well as the ability to fully evaluate the validity of information. As a result, they are particularly susceptible to fake news and pseudo information, which is intensified by their exceedingly short attention spans. In addition, this generation is noted for its unprecedented awareness and acceptance for cultural, racial, and sexual diversity.

The concept of digital natives and digital immigrants was first introduced by Marc Prensky (2001) who said:

Our students today are all native speakers of the digital language of computers, video games and the Internet. So what does that make the rest of us? Those of us who were not born into the digital world but have, at some later point in our lives, become fascinated by and adopted many or most aspects of the new technology are, and always will be compared to them, Digital Immigrants. (p.1)

At the time, Prensky was referring to computers and video game systems as the hallmark technology to digital natives; however, mobile devices and omnipresent social media have grown tremendously since he first introduced his digital native/digital immigrant concept. Technology is now far more engrained in people's lives. Sherry Turkle (2011) presented this technological embeddedness as the concept of tethering, which she explained as "intense one on one relationships with machines" that has led to the development of a "networked culture" where people use technology as the "architect" of intimacies whereas social media is shaping the way people view themselves and their relationships. The literature finds that Generation Z has been raised tethered with mobile technologies, social media, and instant access to Web-based information omnipresent in their lives (Claveria, 2017; Lenhart, 2015; Shatto \& Erwin, 2016; Törőcsik, Szűcs, \& Kehl, 2014; Williams, 2015). Finally, Törőcsik et al. (2014) explain that Generation Z is the first true "global generation" in the world having been encultured from birth to developing a multi-cultural and multi-national mindset.

A Pew Research Center study (Lenhart, 2015) found that Generation Z youth are accustomed to the ease and access of ever present smart phones and other mobile devices with virtually all going online daily and many connected nearly constantly. Use of social media such as Facebook, Instagram, and Snapchat were found to be fairly prevalent as was texting with an average of 30 cell phone texts being sent and received daily. Gaps in access to technology were found along socio-economic, racial, and ethnic lines, especially when access to desktop and laptop computers was considered.

Gibson (2016) explains that Generation Z is going to transform society with their different way of thinking and learning. He asserts that their minds, relationships, learning preferences, emotional health, and sense of self have all been shaped by constant screen exposure from an early age, which has altered their neural circuitry leading to shorter attention spans, stunted social skills, and a heightened ability to multitask (Gibson, 2016).

Törőcsik et al. (2014) conducted a study of Generation Z teenagers in Hungary. They found that this generation's outlook has been totally framed by networked digital technologies so that they prefer short bites of real time information with pictures, have short attention spans, prefer simplification, and spend copious amounts of their free time using mobile devices and social media.

A comparison was done by Claveria (2017) of millennials verses Generation Z and claimed that where millennials have never seen a floppy disc most of Generation $Z$ is unfamiliar with a flip phone, and that Generation Z has a 30\% shorter attention span than millennials, spends less time watching television, and makes more online purchases. Further, where choice overload has been 
found to be a leading stressor of millennials, phone separation anxiety is found to be the biggest stressor of Generation Z.

A lack of technological competency has been shown to be associated with a lower quality of life with higher risks of unemployment (Sparks, Katz, \& Beile, 2016). Further, employers are concerned about the technological proficiency of individuals entering the workforce (Hart Research Associates, 2013) with studies finding that, while recent graduates are savvy when it comes to social media and the internet, they are frequently lacking in the use of core productivity tools and applications (Head, 2012).

A large-scale study reported by Library Journal (Dixon, 2017) found that first-year college and university students entered higher education with widely varying levels of information literacy that is partially caused by a national funding crisis that has left countless $\mathrm{K}-12$ public schools without functioning school libraries and trained school librarians/media specialists. According to the report, less than one-third $(28 \%)$ of first generation college students entered with proper information literacy skills so as to be able to locate and critically evaluate information. The study explains that these deficiencies are exacerbated by students' overconfidence, apathy, and weak attention spans.

Socio-economic factors and issues of the digital divide prevail in importance. Subramony (2014) explains that the digital divide remains one of the biggest challenges in modern times despite the ubiquitous nature of digital technologies. Similarly, a study by Ritzhaupt, Liu, Dawson, and Barron (2013), who examined 5,990 students from 13 school districts across the state of Florida, found that the digital divide remains prevalent in the United States. Further, work by Buzzetto-Hollywood, Elobeid, and Elobaid (2017) found that first-generation students attending a mid-Atlantic historically Black university arrived on campus with digital literacy issues, most notably with severe deficiencies when it came to the use of core computer applications.

In the United States, it is widely recognized that many young adults are not equipped with the skills to succeed as a contributing member of the 21st Century Workforce. The Partnership for 21st Century Skills, which includes such companies as Microsoft, Apple, Cisco, and Pearson, has criticized the American educational system, referring to it as obsolete and outmoded, and has challenged educators to build such crucial skills as critical thinking, problem solving, creativity, oral and writing communications, and technological readiness into the learning process (Eisen, Jasinowski, \& Kleinert, 2005).

Swartz (2017) explains that data from the U.S. Bureau of Labor Statistics and graduation rates predicted by the National Science Foundation indicate that there will be an estimated 1 million more computing jobs than applicants who can fill them by 2020. Compounding the problem, the author explained, is that only $11 \%$ of employers believe higher education is "very effective" in readying graduates to meet skills needed in their organizations with more than $62 \%$ of students responding in surveys that they were unprepared when it comes to the skills needed for workplace success.

A 2016 national survey released by the Society for Human Resource Management (2016) and sponsored by the American Statistical Association, found that over the past five years, nearly two-thirds of organizations $(65 \%)$ studied had increased the number of positions requiring data analysis skills, and more than half $(59 \%)$ expected to increase the number of positions at their organizations over the next five years. Further, employers who filled a data analysis position within the last 12 months noted challenges with $78 \%$ reporting they had difficulty recruiting qualified candidates. Departments found to be most in need of individuals capable of conducting data analyses were accounting and finance (71\%), human resources (54\%), and business and administration $(50 \%)$.

\section{METHODOLOGY}

In the fall of 2017, an online student perception pilot survey was prepared and administered to students enrolled at a mid-Atlantic minority serving institution. A survey method was selected because it enables scholars to explore social psychological phenomena with representative populations with valid and measurable queries (Visser, Krosnick, \& Lavarakas, 2000). The survey was prepared within, 
and delivered using, the Survey Monkey system. The instrument included a combination of dichotomous, Likert-scaled, and ranking questions. The survey was administered to students following completion of core computer concepts courses with students provided time to anonymously complete the survey at the end of an appointed course session. The questions explored participants technology backgrounds, perceived computing self-efficacy, and the role they predict technology will play in their future career. The data was subsequently exported to Microsoft Excel where descriptive statistical analyses were conducted. During the analyses the following hypotheses were explored

\section{$\mathbf{H}_{1-}$ - Generation $\mathrm{Z}$ learners enrolled in a minority serving institution enjoy computer classes.}

This hypothesis was measured with responses to a five-point Likert scaled statement "I enjoy computer classes" whereas it was decided that if a mean of $>3.0$ was achieved, then the threshold for affirming the hypothesis had been met.

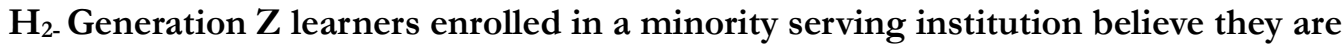 technologically skilled in common technology tools and communication services.}

This hypothesis was measured with responses to a series of five-point Likert scaled statements including:

- "Working with computers comes easy to me" which was measured on a scale from strongly disagree to strongly agree

- "How skilled are you with the following" (computer applications, operating systems, and mobile operating systems) which was measured on a scale from very unskilled to very skilled

- "How familiar are you with the following" (social media, email, smart phones, and web searches) which was measured on a scale from totally unfamiliar to very familiar

It was decided that if an overall mean of $>3.0$ was achieved, then the threshold for affirming the hypothesis had been met.

$\mathrm{H}_{3-}$ Generation $\mathrm{Z}$ learners enrolled in a minority serving institution want to improve their technology skills.

This hypothesis was measured with responses to a series of five-point Likert scaled statements including:

- "I would like to be more technologically literate"

- "I would like to be more skilled in the use of computer software applications"

- 'I would like to know more about computer fundamentals (basic hardware components; networking fundamentals; cloud computer; use, and management of operating systems; and storage options)"

- "I would like to know more about cybersecurity"

It was decided that if an overall mean of $>3.0$ was achieved, then the threshold for affirming the hypothesis had been met.

$\mathrm{H}_{4}$ - Generation $\mathrm{Z}$ learners enrolled in a minority serving institution believe that technology will impact their future career.

This hypothesis was measured with responses to a series of five-point Likert scaled statements including: "Technology will play a major role in my future career", "My future career will require me to use technology to analyze information to inform decision making", and "Employers want to see job applications with good technology skills" where it was decided that if a mean of $>3.0$ was achieved, then the threshold for affirming the hypothesis had been met. 


\section{FINDINGS}

There were 160 students who completed the survey representing a response rate of $>75 \%$ with most of the respondents noting that it is important for college students to take computer courses $\mu=4.12$. In this section each of the hypotheses are tested and related back to the literature

$\mathbf{H}_{1-}$ - Generation $\mathbf{Z}$ learners enrolled in a minorit y serving institution enjoy computer classes.

This hypothesis was considered by examining responses to a five-point Likert scaled statement " $T$ enjoy computer classes" and is represented in Table 1 where a mean of 3.74, a standard deviation of 1.84 , and a confidence interval at $95 \%$ of .168 . With a mean of $>3.0$ this hypothesis is determined as having been met with findings consistent to what has been reported by Buzzetto-Hollywood (2017).

\begin{tabular}{|c|c|c|c|c|c|c|c|c|}
\hline $\mathbf{N}=160$ & $\begin{array}{l}\text { Strongly } \\
\text { Disagree } \\
\text { (1)- }\end{array}$ & $\begin{array}{l}\text { Disagree } \\
\text { (2)- }\end{array}$ & Neutral (3)- & Agree (4)- & $\begin{array}{l}\text { Strongly } \\
\text { Agree (5)- }\end{array}$ & MEAN & STDV & CONF \\
\hline $\begin{array}{l}\text { I enjoy } \\
\text { computer } \\
\text { classes }\end{array}$ & $\begin{array}{r}6.88 \% \\
11\end{array}$ & $\begin{array}{r}3.75 \% \\
6\end{array}$ & $\begin{array}{r}22.50 \% \\
36\end{array}$ & $\begin{array}{r}42.50 \% \\
68\end{array}$ & $\begin{array}{r}24.38 \% \\
39\end{array}$ & 3.74 & 1.84 & .168 \\
\hline
\end{tabular}

$\mathbf{H}_{2}$ - Generation $\mathrm{Z}$ learners enrolled in a minority serving institution believe they are technologically skilled in common technology tools and communication services.

This hypothesis was measured with responses to a series of five-point Likert scaled statements. Table 2 considers responses to the statement "Working with computers comes easy to me" which was measured on a scale from strongly disagree to strongly agree with a mean of 3.86 , a standard deviation of 1.025 , and a confidence interval at $95 \%$ of .159 found.

\begin{tabular}{|c|c|c|c|c|c|c|c|c|}
\hline $\mathbf{N}=160$ & $\begin{array}{l}\text { Strongly } \\
\text { Disagree } \\
\text { (1)- }\end{array}$ & $\begin{array}{l}\text { Disagree } \\
\text { (2)- }\end{array}$ & Neutral (3)- & Agree (4)- & $\begin{array}{l}\text { Strongly } \\
\text { Agree (5)- }\end{array}$ & MEAN & STDV & CONF \\
\hline $\begin{array}{l}\text { Working } \\
\text { with } \\
\text { computers } \\
\text { comes } \\
\text { easy to me }\end{array}$ & $\begin{array}{r}4.38 \% \\
7\end{array}$ & $\begin{array}{r}4.38 \% \\
7\end{array}$ & $\begin{array}{r}20.63 \% \\
33\end{array}$ & $\begin{array}{r}41.88 \% \\
67\end{array}$ & $\begin{array}{r}28.75 \% \\
46\end{array}$ & 3.86 & 1.025 & .159 \\
\hline
\end{tabular}

Table 3 considered responses to the query "How skilled are you with the following" (computer applications, operating systems, mobile operating systems, and information processing) which was measured on a scale from very unskilled to very skilled with a mean of 3.91, a standard deviation of .809 and a confidence interval of .125 found for computer applications; a mean of 4.18, a standard deviation of .846 and a confidence interval of .135 for desktop/laptop operating systems; and a mean of 4.33 , a standard deviation of .838 and a confidence interval of .130 for mobile operating systems.

\begin{tabular}{l|r|r|r|r|r|r|r|r}
\hline & \multicolumn{9}{c}{ Table 3: Respondents Skills } \\
N=160 & $\begin{array}{l}\text { Strongly } \\
\text { Disagree } \\
\text { (1)- }\end{array}$ & $\begin{array}{l}\text { Disagree } \\
(2)-\end{array}$ & Neutral (3)- Agree (4)- $\begin{array}{l}\text { Strongly } \\
\text { Agree (5)- }\end{array}$ & MEAN & STDV & CONF \\
\hline $\begin{array}{l}\text { Overall use } \\
\text { of comput- } \\
\begin{array}{l}\text { er applica- } \\
\text { tions }\end{array}\end{array}$ & $2.63 \%$ & $3.95 \%$ & $9.87 \%$ & $67.11 \%$ & $16.4 \%$ & & & \\
\hline
\end{tabular}




\begin{tabular}{|c|c|c|c|c|c|c|c|c|}
\hline \multicolumn{9}{|c|}{ Table 3: Respondents Skills } \\
\hline $\mathbf{N}=160$ & $\begin{array}{l}\text { Strongly } \\
\text { Disagree } \\
(1)-\end{array}$ & $\begin{array}{l}\text { Disagree } \\
(2)-\end{array}$ & Neutral (3)- & Agree (4)- & $\begin{array}{l}\text { Strongly } \\
\text { Agree (5)- }\end{array}$ & MEAN & STDV & CONF \\
\hline $\begin{array}{l}\text { Use of } \\
\text { Operating } \\
\text { Systems } \\
\text { (Windows, } \\
\text { Mac OS, or } \\
\text { Chrome) }\end{array}$ & $\begin{array}{r}1.31 \% \\
2\end{array}$ & $\begin{array}{r}3.27 \% \\
5\end{array}$ & $\begin{array}{r}10.46 \% \\
16\end{array}$ & $\begin{array}{r}45.75 \% \\
70\end{array}$ & $\begin{array}{r}39.22 \% \\
60\end{array}$ & 4.18 & .846 & .135 \\
\hline $\begin{array}{l}\text { Use of } \\
\text { Mobile } \\
\text { Operating } \\
\text { Systems } \\
\text { (e.g. Apple } \\
\text { iOS or } \\
\text { Google } \\
\text { Android) }\end{array}$ & $\begin{array}{r}1.29 \% \\
2\end{array}$ & $\begin{array}{r}2.58 \% \\
4\end{array}$ & $\begin{array}{r}8.39 \% \\
13\end{array}$ & $\begin{array}{r}37.42 \% \\
58\end{array}$ & $\begin{array}{r}50.32 \% \\
78\end{array}$ & 4.33 & .838 & .130 \\
\hline
\end{tabular}

Table 4 considered familiarity with a range of common activities including social media, email, smartphones, and Web searches. Respondents indicated strong familiarity with each including social media $(\mu=4.47, \sigma \mathrm{X}=. .969$, and $\mathrm{CI}=.150)$, email $(\mu=4.68, \sigma \mathrm{X}=.764$, and $\mathrm{CI}=.118)$, smartphones $(\mu=4.78, \sigma \mathrm{X}=.647$, and $\mathrm{CI}=.1)$, and Web searches $(\mu=4.76, \sigma \mathrm{X}=.733$, and $\mathrm{CI}=.111)$.

\begin{tabular}{|c|c|c|c|c|c|c|c|c|}
\hline \multicolumn{9}{|c|}{ Table 4: Familiarity } \\
\hline $\mathbf{N}=160$ & $\begin{array}{l}\text { Strongly } \\
\text { Disagree } \\
\text { (1)- }\end{array}$ & $\begin{array}{l}\text { Disagree } \\
(2)-\end{array}$ & Neutral (3)- & Agree (4)- & $\begin{array}{l}\text { Strongly } \\
\text { Agree (5)_- }\end{array}$ & MEAN & STDV & CONF \\
\hline $\begin{array}{l}\text { Social Media } \\
\text { (e.g. Face- } \\
\text { book, Twit- } \\
\text { ter, Insta- } \\
\text { gram, or } \\
\text { SnapChat) }\end{array}$ & $\begin{array}{r}3.25 \% \\
5\end{array}$ & $\begin{array}{r}3.90 \% \\
6\end{array}$ & $\begin{array}{r}3.25 \% \\
5\end{array}$ & $\begin{array}{r}11.69 \% \\
18\end{array}$ & $\begin{array}{r}77.92 \% \\
120\end{array}$ & 4.57 & .969 & .150 \\
\hline Email & $\begin{array}{r}1.95 \% \\
3\end{array}$ & $\begin{array}{r}0.65 \% \\
1\end{array}$ & $\begin{array}{r}4.55 \% \\
7\end{array}$ & $\begin{array}{r}12.99 \% \\
20\end{array}$ & $\begin{array}{r}79.87 \% \\
123\end{array}$ & 4.68 & .764 & 0.118 \\
\hline $\begin{array}{l}\text { Using A } \\
\text { Smartphone }\end{array}$ & $\begin{array}{r}0.65 \% \\
1\end{array}$ & $\begin{array}{r}1.29 \% \\
2\end{array}$ & $\begin{array}{r}4.52 \% \\
7\end{array}$ & $\begin{array}{r}6.45 \% \\
10\end{array}$ & $\begin{array}{r}87.10 \% \\
135\end{array}$ & 4.78 & .647 & .1 \\
\hline $\begin{array}{l}\text { Searching } \\
\text { the Web }\end{array}$ & $\begin{array}{r}1.95 \% \\
3\end{array}$ & $\begin{array}{r}0.65 \% \\
1\end{array}$ & $\begin{array}{r}3.90 \% \\
6\end{array}$ & $\begin{array}{r}6.49 \% \\
10\end{array}$ & $\begin{array}{r}87.01 \% \\
134\end{array}$ & 4.76 & .733 & .111 \\
\hline
\end{tabular}

Without exception, and with respect to all statements and questions, all means were $>3.0$ thus affirming the hypothesis that students are confident in their technological abilities including use of basic computer applications, social media, email, smart phones, and searching the Web. These findings are consistent with what has been reported by Buzzetto-Hollywood et al. (2017), Lenhart (2015), Hanson, Kilcoyne, Perez-Mira, Hanson, and Champion (2011), Marakas, Johnson, and Clay (2007), and Smith, Given, Julien, Ouellette, and DeLong (2013). 
Several studies have concluded that students entering college today have mastered the small portion of familiar technologies that they use on a daily basis (Buzzetto-Hollywood et al., 2017; Hargatti, 2005; Mishra, Cellante, \& Kavanaugh, 2015;) such as social media, email, and cell phone and Web usage but lack the skills to use technology to more critically evaluate information (BuzzettoHollywood, 2017; Head, 2012; Mishra et al., 2015). This was affirmed in this study when two agreement questions were considered that looked at students familiarity with modeling software, statistical software, and software used for data analytics where the respondents noted a lack of familiarity with all means $<3.0$.

\section{$\mathrm{H}_{3-}$ Generation $\mathrm{Z}$ learners enrolled in a minority serving institution want to improve their technology skills.}

This hypothesis was measured by considering responses to a series of five-point Likert scaled statements, all of which are represented in Table 5, which considers students interests in improving their technology skills. As demonstrated in Table 5, respondents indicated interest in becoming more technologically literate $(\mu=4.08, \sigma \mathrm{X}=1.043$, and $\mathrm{CI}=.162)$, improving their ability to use software applications $(\mu=3.91, \sigma \mathrm{X}=1.012$, and $\mathrm{CI}=.157)$, extending their knowledge of computing fundamentals $(\mu=3,72, \sigma \mathrm{X}=1.010$, and $\mathrm{CI}=.157)$, and becoming more familiar with cybersecurity $(\mu=$ $3.78, \sigma \mathrm{X}=1.114$, and $\mathrm{CI}=.173$ ). With all of the means $>3.0$, this hypothesis is viewed as being affirmed and is consistent with what has been reported in the literature by Buzzetto-Hollywood (2017), Dahlstrom, Walker, and Dziuban (2014), and Nataraj (2014).

\begin{tabular}{|c|c|c|c|c|c|c|c|c|}
\hline \multicolumn{9}{|c|}{ Table 5: Interest In Improving Their Technology Skills } \\
\hline $\mathbf{N}=160$ & $\begin{array}{l}\text { Strongly } \\
\text { Disagree } \\
\text { (1)- }\end{array}$ & $\begin{array}{l}\text { Disagree } \\
(2)-\end{array}$ & Neutral (3)- & Agree (4)- & $\begin{array}{l}\text { Strongly } \\
\text { Agree (5)- }\end{array}$ & MEAN & STDV & CONF \\
\hline $\begin{array}{l}\text { I would } \\
\text { like to } \\
\text { improve } \\
\text { my overall } \\
\text { techno- } \\
\text { logical } \\
\text { literacy }\end{array}$ & $\begin{array}{r}5.00 \% \\
8\end{array}$ & $\begin{array}{r}1.25 \% \\
2\end{array}$ & $\begin{array}{r}16.88 \% \\
27\end{array}$ & $\begin{array}{r}35.00 \% \\
56\end{array}$ & $\begin{array}{r}41.88 \% \\
67\end{array}$ & 4.08 & 1.043 & .162 \\
\hline $\begin{array}{l}\text { I would } \\
\text { like to be } \\
\text { more } \\
\text { skilled in } \\
\text { the use of } \\
\text { computer } \\
\text { software } \\
\text { applica- } \\
\text { tions }\end{array}$ & $\begin{array}{r}5.00 \% \\
8\end{array}$ & $\begin{array}{r}2.50 \% \\
4\end{array}$ & $\begin{array}{r}18.13 \% \\
29\end{array}$ & $\begin{array}{r}45.00 \% \\
72\end{array}$ & $\begin{array}{r}29.38 \% \\
47\end{array}$ & 3.91 & 1.012 & .157 \\
\hline
\end{tabular}




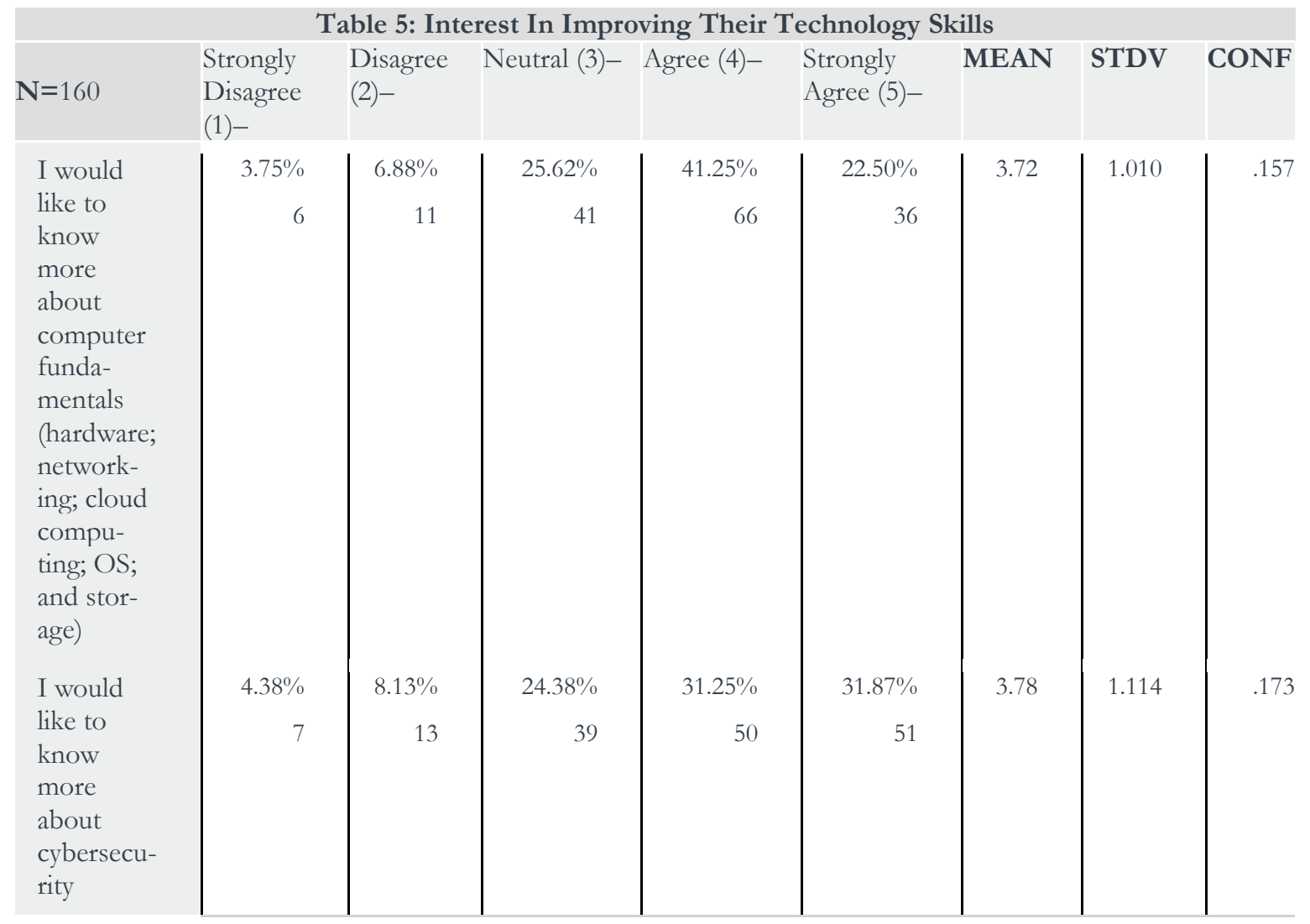

$\mathrm{H}_{4}$ - Generation $\mathrm{Z}$ learners enrolled in a minority serving institution believe that technology will impact their future career.

This hypothesis was measured by considering responses to three five-point Likert scaled statements, all of which are represented in Table 6,where students agreed that technology will play an important role in their future career $(\mu=4.14, \sigma \mathrm{X}=.961$, and $\mathrm{CI}=.149)$; their future will require them to use technology to analyze information to inform decision making $(\mu=3.95, \sigma \mathrm{X}=1.043$, and $\mathrm{CI}=.162)$; and that employers want to see job applicants with good technology skills $(\mu=4.11, \sigma \mathrm{X}=.951$, and $\mathrm{CI}=.147)$. With all means $>3.0$, this hypothesis is viewed as being affirmed and is consistent with what has been reported in the literature (Hart Research Associates, 2013; Society for Human Resource Management, 2016; Swartz, 2017).

\begin{tabular}{|c|c|c|c|c|c|c|c|c|}
\hline \multicolumn{9}{|c|}{ Table 6: Respondents Perceptions Of The Impact Of Technology On Their Future } \\
\hline $\mathbf{N}=160$ & $\begin{array}{l}\text { Strongly } \\
\text { Disagree } \\
(1)-\end{array}$ & $\begin{array}{l}\text { Disagree } \\
(2)-\end{array}$ & Neutral (3)- & Agree (4)- & $\begin{array}{l}\text { Strongly } \\
\text { Agree (5)- }\end{array}$ & MEAN & STDV & $\begin{array}{l}\text { CON } \\
\text { F }\end{array}$ \\
\hline $\begin{array}{l}\text { Technol- } \\
\text { ogy will } \\
\text { play a } \\
\text { major role } \\
\text { in my } \\
\text { future } \\
\text { career }\end{array}$ & $\begin{array}{r}2.58 \% \\
4\end{array}$ & $\begin{array}{r}1.94 \% \\
3\end{array}$ & $\begin{array}{r}18.71 \% \\
29\end{array}$ & $\begin{array}{r}32.90 \% \\
51\end{array}$ & $\begin{array}{r}43.87 \% \\
68\end{array}$ & 4.14 & .961 & .149 \\
\hline $\begin{array}{l}\text { My future } \\
\text { career will } \\
\text { require } \\
\text { me to use }\end{array}$ & $\begin{array}{r}3.23 \% \\
5\end{array}$ & $\begin{array}{r}6.45 \% \\
10\end{array}$ & $\begin{array}{r}18.06 \% \\
28\end{array}$ & $\begin{array}{r}36.77 \% \\
57\end{array}$ & $\begin{array}{r}35.48 \% \\
55\end{array}$ & 3.95 & 1.043 & .162 \\
\hline
\end{tabular}




\begin{tabular}{|c|c|c|c|c|c|c|c|c|}
\hline \multicolumn{9}{|c|}{ Table 6: Respondents Perceptions Of The Impact Of Technology On Their Future } \\
\hline $\mathbf{N}=160$ & $\begin{array}{l}\text { Strongly } \\
\text { Disagree } \\
\text { (1)- }\end{array}$ & $\begin{array}{l}\text { Disagree } \\
(2)-\end{array}$ & Neutral (3)- & Agree (4)- & $\begin{array}{l}\text { Strongly } \\
\text { Agree (5)- }\end{array}$ & MEAN & STDV & $\begin{array}{l}\text { CON } \\
\text { F }\end{array}$ \\
\hline $\begin{array}{l}\text { technolo- } \\
\text { gy to ana- } \\
\text { lyze in- } \\
\text { formation } \\
\text { to inform } \\
\text { decision } \\
\text { making }\end{array}$ & & & & & & & & \\
\hline $\begin{array}{l}\text { Employ- } \\
\text { ers want } \\
\text { to see job } \\
\text { applica- } \\
\text { tions with } \\
\text { good } \\
\text { technolo- } \\
\text { gy skills }\end{array}$ & $\begin{array}{r}2.58 \% \\
4\end{array}$ & $\begin{array}{r}3.23 \% \\
5\end{array}$ & $\begin{array}{r}14.84 \% \\
23\end{array}$ & $\begin{array}{r}39.35 \% \\
61\end{array}$ & $\begin{array}{r}40.00 \% \\
62\end{array}$ & 4.11 & .951 & .147 \\
\hline
\end{tabular}

\section{DISCUSSION}

Generation $\mathrm{Z}$ are digital natives (Williams, 2015) who have been found in the literature to be tethered to, dependent on, and comfortable with, mobile devices, the internet, and social media (Claveria, 2017; Lenhart, 2015; Shatto \& Erwin, 2016; Törőcsik, Szűcs, \& Kehl, 2014; Williams, 2015) and this pilot study has provided detailed confirmation of the literature especially as it applies to minority learners. Additionally, Generation $\mathrm{Z}$ is confident, perhaps overly so, in both the literature and this study, in their technological abilities in the use of basic computer applications, social media, email, smart phones, and searching the Web (Buzzetto-Hollywood et al., 2017; Lenhart, 2015; Smith et al., 2013). And where staffing studies and reports continue to show the ever-increasing value of technology skills for new hires and recent college graduates (Hart Research Associates, 2013; Society for Human Resource Management, 2016; Swartz, 2017), the students in this study also report that technology will play a major role in their future career and exhibit an interest in enhancing their technological skills and overall readiness similarly to what has been reported by such studies as Dahlstrom et al. (2014.)

Generation Z learners enrolled in higher education want a wide range of technology learning opportunities available to them in order to help them meet the rapidly evolving demands of tomorrow's workplace. Students overwhelmingly see the value in enhancing their technology skills, especially in such areas as computer software applications, information management, and cyber security. Further, the findings indicate that institutions of higher education should invest in a thorough examination of technology skills, needs, and perceptions of students entering the institution. This investigation should be ongoing in order to reflect the evolving technology skill expectations desired in higher education and the workplace.

\section{LIMITATIONS}

The greatest limitation of this study is that is focused exclusively on students attending a single institution. However, at the same time, this study provides research on a population that is expanding in numbers in higher education and that many educators, and much research, reports as being underprepared for academic success (Allen, 1987; Buzzetto-More \& Sweat-Guy, 2007). 
Additionally, this survey was administered after students had completed a core computer concepts class, as such that may have increased their positive perceptions of their skills. This possible flaw is being remedied in the next phase of this study, which will be administered to students enrolled in freshmen experience courses. This study has also been expanded to include multiple institutions and more demographic and lifestyle questions in its next iteration.

Finally, there is a paucity of available literature on Generation Z learners in higher education. This shortage makes making comparisons to the literature challenging. At the same time, it highlights the need for, and value of, studies such as this study.

\section{CONCLUSIONS}

As Generation $Z$ descends on college campuses, with their technology dominated backgrounds and different communications, learning, and social preferences, it is important to better understand this generation whose needs and expectations will help shape the future of higher education. The findings show that Generation $Z$ learners enrolled at a minority serving institution enjoy computer classes, feel that using computers comes easy to them; are experts in the use of social media, mobile operating systems, using a smart phone, searching the Web, and email.; want to be more technologically literate, more skilled in computer software applications, and are interested in learning about cyber security. In terms of the future, most believe that technology will play a major role in their future career where employers will want job applicants with strong technology skills, and where the workplace will require them to analyze information to inform decision making.

\section{REFERENCES}

Allen, W. (1987). Black college vs. white college: The fork in the road for black students. Change, 19, 28-34. https://doi.org/10.1080/00091383.1987.9939144

Buzzetto-More, N., \& Sweat-Guy, R. (2007). Digital natives: Exploring the technology experiences and uses of the millennium generation. Journal of Global Information Technology. 1(12, 78-87

Buzzetto-Hollywood, N. (2017). Establishing an institutional commitment to the digital and information literacy of under-served college students. In F. Reisman \& S. DiPietro (Eds.). Best Papers of the 2017 Drexel Assessment Conference (pp. 14-27). Philadelphia, P.A.

Buzzetto-Hollywood, N., Elobeid. M., \& Elobaid, M. (2017). Assessing and addressing the digital literacy skills of firstgeneration college students. Paper presented at The Annual Conference on Teaching Learning and Assessment, Philadelphia, PA, September 13-15, 2017.

Claveria, K. (2017). Unlike millennials: 5 ways Gen Z differs from Gen Y. Retrieved from https://www.visioncritical.com/gen-z-versus-millennials-infographics/

Dahlstrom, E., Walker, J. D., \& Dziuban, C. (2014). ECAR Study of undergraduate students and information technology 2013. Retrieved from https://library.educause.edu/resources/2013/9/ecar-study-of-undergraduatestudents-and-information-technology-2013

Dixon, J. (2017). First impressions: LJ's first year experience survey. Library Journal. Retrieved from http://li.libraryjournal.com/2017/04/academic-libraries/first-impressions-ljs-first-year-experiencesurvey/

Eisen, P., Jasinowski, J., \& Kleinert, R. (2005). 2005 Skills gap report. Retrieved from http://www.themanufacturinginstitute.org/ /media/738F5D310119448DBB03DF30045084EF/2005 Sk ills Gap Report.pdf

Gibson, C. (2016). Who are these kids? Inside the race to decipher today's teens, who will transform society as we know it. Washington Post. Retrieved from http://www.washingtonpost.com/sf/style/2016/05/25/inside-the-race-to-decipher-todays-teens-whowill-transform-society-as-we-know-it/?utm term $=.0550 \mathrm{a} 2 \mathrm{ed} 10 \mathrm{fd}$ 
An Examination of Gen Z Learners Attending a Minority University

Hanson, B., Kilcoyne, M., Perez-Mira, B., Hanson, T., \& Champion, S. (2011). Digital knowledge and application skills: A comparison study of entering freshman. Journal of Research in Business Information Systems, 4(4), $55-68$.

Hargittai, E. (2005). Survey measures of web-oriented digital literacy. Social Science Computer Review, 23(3), 371379. https://doi.org/10.1177/0894439305275911

Hart Research Associates. (2013). What do employers want from college graduates? Liberal Education, 99(2), 2229.

Head, A. (2012). Learning curve: How college graduates solve information problems once they join the workplace. https://doi.org/10.2139/ssrn.2165031

Lenhart, A. (2015). Pew Research Center report: Teens, social media, and technology overview 2015. Retrieved from http://www.pewinternet.org/2015/04/09/teens-social-media-technology-2015/

Marakas, G., Johnson, R., \& Clay, P. (2007). The evolving nature of the computer self-efficacy construct: An empirical investigation of measurement construction, validity, reliability, and stability over time. Journal of Association for Information Systems, 8(1), 16-46. https://doi.org/10.17705/1jais.00112

Mishra, S., Cellante, D., \& Kavanaugh, L. (2015). Assessing the usefulness of a core introductory information systems course in undergraduate curriculum: An experimental study. Issues in Information Systems, 16(1), 31 40 .

Nataraj, S. (2014). The need for an introductory computer literacy course at the university level. International Journal of Business Management and Economic Research, 5(4), 71-73.

Prensky, M. (2001). Digital natives, digital immigrants part 1.On the Horizon, 9(5), 1-6. https://doi.org/10.1108/10748120110424816

Ritzhaupt, A., Liu, F., Dawson, K., and Barron, A. (2013). Differences in student information and communication technology literacy based on socio-economic status, ethnicity, and gender: evidence of a digital divide in Florida. Journal of Research on Technology in Education, 45(4), 291-307. https://doi.org/10.1080/15391523.2013.10782607

Shatto, B., \& Erwin, K. (2016). Moving on from millennials: Preparing for Generation Z. The Journal of Continuing Education in Nursing, 47(6), 253-254. https://doi.org/10.3928/00220124-20160518-05

Smith, J. K., Given, L. M., Julien, H., Ouellette, D., \& DeLong, K. (2013). Information literacy proficiency: Assessing the gap in high school students' readiness for undergraduate academic work. Library \& Information Science Research, 35(2), 88-96. https://doi.org/10.1016/j.lisr.2012.12.001

Society for Human Resources Management. (2016). Jobs of the future: data analysis skills. Retrieved from https://www.amstat.org/asa/files/pdfs/Data-Analysis-Skills SHRM Survey.pdf

Sparks, J. R., Katz, I. R., \& Beile, P. M. (2016). Assessing digital information literacy in higher education: A review of existing frameworks and assessments with recommendations for next-generation assessment. ETS Research Report Series 2016, 1-33. https://doi.org/10.1002/ets2.12118

Subramony, D. (2014). Revisiting the digital divide in the context of a flattening world. Educational Technology, 54(2), 3-9.

Swartz, J. (2017). Businesses say they just can't find the right tech workers. USA Today. Retrieved from https://www.usatoday.com/story/tech/talkingtech/2017/03/28/tech-skills-gap-huge-graduates-surveysays/99587888/

Törőcsik, M., Szűcs, K., \& Kehl, D. (2014). How generations think: research on Generation Z. Acta Universitatis Sapientiae, Communicatio, 1, 23-45.

Turkle, S. (2011). The tethered self: Technology reinvents intimacy and solitude. Continuing Higher Education Review, 75(1), 28-31.

Visser, P., Krosnick, J., \& Lavarakas, P. (2000). Chapter9: Survey research. In H. Reiss \& J. Charles, Handbook of research methods in social and personality psychology. Cambridge, MA. Cambridge University Press. 
Williams, A. (2015). Move over, millennials, here comes Generation Z. New York Times. Retrieved from https://www.nytimes.com/2015/09/20/fashion/move-over-millennials-here-comes-generation-z.html

\section{BIOGRAPHIES}

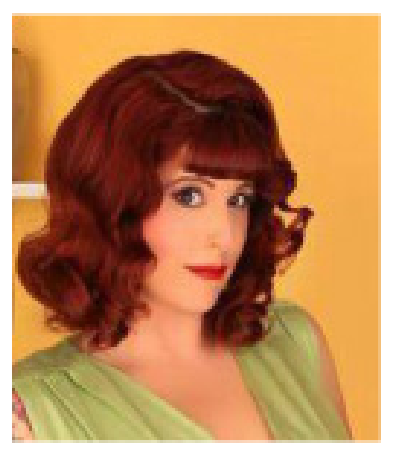

Dr. Nicole A. Buzzetto-Hollywood (formerly Buzzetto-More) is a Professor, Program Coordinator, and the Assurance of Learning and Assessment Chair in the Department of Business at the University of Maryland Eastern Shore. She received her doctorate and master's degrees from Columbia University and earned a post doctorate from Tulane University. She also earned a master's degree from the College of New Rochelle and a bachelor's degree from Marist College. A frequent presenter at conferences, she is on the editorial board of several journals; has authored over 40 peer reviewed journal articles as well as three books and several book chapters; and has been recognized with awards from the American Distance Education Consortium, Global Digital Business Association, and the Informing Science Institute. Her areas of expertise include educational assessment and accreditation, instructional design, e-learning, instructional technology, management education, eportfolios, communications, curriculum development, innovations in teaching and learning, marketing, and new media.

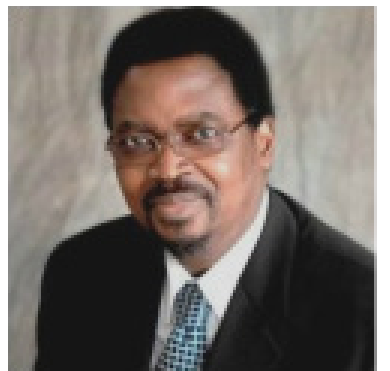

as a land grant institution.
Dr. Ayodele J. Alade is the former Dean of the UMES School of Business and Technology at the University of Maryland Eastern Shore. Under his leadership, the unprecedented growth and program enhancements occurred. With these developments, curricula in various programs were reassessed to meet Department designated accreditation standards, new courses were developed to serve the interest of students as well as meet the new challenges in the market place, the volume of meaningful academic research and competitive grants were increased, and new programs were proposed and developed in accordance with the institution's mission 